\title{
A new Middle Devonian cystoporate bryozoan from Germany containing a new symbiont bioclaustration
}

\author{
Andrej Ernst, Paul D. Taylor, and Jan Bohatý \\ Acta Palaeontologica Polonica 59 (1), 2014: 173-183 doi: http://dx.doi.org/10.4202/app.2010.0110
}

An unusual cystoporate bryozoan from the Middle Devonian (Givetian) Ahbach Formation of the Hillersheim Syncline (Eifel, Rhenish Massif, Germany) is described as Stellatoides muellertchensis gen. et sp. nov. The lamellar colonies have elongate stellate maculae with depressed centres consisting of vesicular skeleton. All colonies collected contain vertical axial tubular holes, which are embedment structures formed by the bryozoan around a soft-bodied symbiont and lined by bryozoan skeleton. These bioclaustrations are referred to the ichnogenus Chaetosalpinx, previously known in Ordovician-Devonian corals and sponges, and are described as Chaetosalpinx tapanilai ichnosp. nov. Ecological analogues to Chaetosalpinx tapanilai can be found in modern bryozoans in which tubes formed of bryozoan calcite are occupied by spionid polychaetes, or less often tanaidacean crustaceans.

Key words: Bryozoa, taxonomy, bioclaustration, evolution, Devonian, Germany.

Andrej Ernst [Andrej.Ernst@uni-hamburg.de], Institut für Geologie, Universität Hamburg, Bundesstr. 55, 20146 Hamburg, Germany; Paul D. Taylor [p.taylor@nhm.ac.uk ], Department of Palaeontology, Natural History Museum, Cromwell Road, London SW7 5BD, United Kingdom; Jan Bohatý [bohaty.jan@googlemail.com], Sachgebiet Paläontologische Denkmalpflege der hessenARCHÄOLOGIE am Landesamt für Denkmalpflege Hessen, Schloss Biebrich/Ostflügel, Rheingaustraße 140, 65203 Wiesbaden, Germany.

This is an open-access article distributed under the terms of the Creative Commons Attribution License (for details please see creativecommons.org), which permits unrestricted use, distribution, and reproduction in any medium, provided the original author and source are credited. 
For Full text $(1,478.6 \mathrm{kB})$ 